\title{
Urban Gardens' Potential to Improve Stormwater Management: A Comparative Analysis among Urban Soils in Sorocaba, São Paulo, Brazil
}

\author{
Carina Júlia Pensa Corrêa ${ }^{1, * \mathbb{D}}$, Ernest O. Nnadi ${ }^{2}$, Fredrick U. Mbanaso ${ }^{2}$ and Kelly Cristina Tonello ${ }^{1}$ (D) \\ 1 Hydrology in Forest Ecosystems (Hidrolef), Federal University of São Carlos (UFSCar), \\ Sorocaba 18052-780, Brazil; kellytonello@ufscar.br \\ 2 Centre for Agroecology, Water and Resilience (CAWR), Coventry University, Coventry CV8 3LG, UK; \\ dr.nnadi@gmail.com (E.O.N.); mbanasof@uni.coventry.ac.uk (F.U.M.) \\ * Correspondence: carinapensa@gmail.com
}

check for updates

Citation: Corrêa, C.J.P.; Nnadi, E.O.; Mbanaso, F.U.; Tonello, K.C. Urban Gardens' Potential to Improve Stormwater Management: A Comparative Analysis among Urban Soils in Sorocaba, São Paulo, Brazil. Sustainability 2022, 14, 2965. https:/ / doi.org/10.3390/su14052965

Academic Editors: Andrea Appolloni and George D. Bathrellos

Received: 31 January 2022 Accepted: 28 February 2022 Published: 3 March 2022

Publisher's Note: MDPI stays neutral with regard to jurisdictional claims in published maps and institutional affiliations.

Copyright: (C) 2022 by the authors. Licensee MDPI, Basel, Switzerland. This article is an open access article distributed under the terms and conditions of the Creative Commons Attribution (CC BY) license (https:// creativecommons.org/licenses/by/ $4.0 /)$.

\begin{abstract}
Permeable surfaces are increasingly rare in urban centers, but they have the utmost importance for stormwater infiltration. In this context, green spaces are key to reducing problems caused by runoff. This work aimed to evaluate the physical characteristics of the soil used for agroecological gardening, in comparison with parks, wasteland, and riparian forest in Sorocaba, São Paulo, Brazil. During the one-year data collection, urban gardens were superior to other areas in hydraulic conductivity $\left(35.8 \mathrm{~mm} \mathrm{~h}^{-1}\right)$, humidity $(25.8 \%)$, and soil penetration resistance (1.21 MPa). On the other hand, the riparian forest showed signs of soil degradation, with low water infiltration rates $\left(121.9 \mathrm{~mm} \mathrm{~h}^{-1}\right)$ and humidity $(14.4 \%)$. These findings highlight the importance of better soil management solutions to avoid compaction, such as the protection and conservation of riparian forests. Furthermore, the encouragement of urban gardens and parks with multiple uses can be an option for the enhancement of stormwater management in cities, since this practice has the potential to improve the physical characteristics of urban soils and provide several ecosystem services.
\end{abstract}

Keywords: agroecology; ecosystem service; green spaces; land use; permeable surfaces; urban garden

\section{Introduction}

Stormwater management in large centers has been traditionally based on gray infrastructures, with concrete sinks, runoff collection, transportation pipelines, and wastewater treatment facilities $[1,2]$. However, there are alternatives focused on water infiltration that can improve water management, such as blue-green infrastructure, urban green spaces, and urban river parks [3]. These spaces can reduce peaks and urban runoff volumes and prevent various social and environmental problems [4-7]. Moreover, they can generate ecosystem services such as thermal comfort, improved air quality, increased biodiversity, landscape connectivity, pollinator attraction, and population well-being [8-13].

Although the number of these techniques is gradually increasing worldwide, their large-scale application is still challenging [14,15], and there are still few cases of green infrastructure application and success in Brazilian cities [16]. Thus, an alternative is to assess how permeable urban areas that already exist in cities can contribute to water infiltration. Arboriculture deserves special consideration as rainwater control and there are several applications in urban cities, where trees are integrated in the urban landscape [17]. For example, the City of Mitcham, Australia, successfully retrofitted twelve permeable pavement sections and tree planting pits along verges in a residential street delivering ecosystem functions on urban landscape $[18,19]$. In addition to the provision of aesthetic, environmental, and economic functions, trees have been shown to enhance air pollution mitigation [20], increase stormwater attenuation and evaporation [17,21,22], reduce noise pollution [23], help to reduce the effects of the urban heat island [21,24], increase real estate 
value of buildings [25], provide energy saving function [26,27], and protect buildings [28]. Trees interact with the urban water cycle by intercepting incoming rainfall, removing soil water through transpiration, and increasing infiltration. They are also extremely important for water quality maintenance [29].

However, there are practices that urban populations have developed over the years that did not have the specific objective of water regulation but can assist in environmental recovery and conservation. For instance, urban gardening provides several positive impacts in addition to food production [30-32]. These spaces can generate all categories of ecosystem services: support, Regulation, provision, and cultural [33].

Provision of water regulation service is an example, since gardens are permeable areas that can contribute to the stormwater management [34]. However, to understand the extent of these benefits, it is also necessary to understand the soil-water relationship in other urban permeable areas. The reaction of a permeable soil in the face of a rain event can be investigated through some physical characteristics, such as soil density, soil moisture content, and evapotranspiration. Soil density depends on its structure and reflects the arrangement of its particles, which defines the characteristics of the porous system [35]. Soil moisture indicates the fraction of porous space occupied by water [36], and its determination is important for the viability of plant growth [37], evapotranspiration [38], and for risk assessment of runoff and soil erosion [39].

Hydraulic conductivity is the soil's ability to conduct water from the upper to the deepest layers; it is often higher in the first layers and decreases with increasing depth [35]. In saturated soils, all pores are full and conductive, so their values are maximum. However, under natural conditions with unsaturated soils, some pores are filled with air and the conductive portion of the transverse soil area decreases proportionally [36,40]. Causally related to conductivity is the water infiltration velocity, which represents the maximum flow rate per unit area and per unit of time capable of crossing the soil surface [41]. This parameter reflects the ability of soil to absorb water from rain or irrigation [42] and is also related to runoff and erosion processes [43].

Anthropogenic impacts on the environment can influence the characteristics of soils. Some of the main examples are studies projecting the increase in erosion globally because of climate change [44,45]. In addition, the use of chemical fertilizers can affect the biological activity in the soil. On the other hand, sustainable management can interact positively with the physical characteristics of the soil and with its enzymatic activities, and mitigate the environmental impacts [46]. In this context, this study aimed to evaluate the soil characteristics of urban gardens and understand how these spaces can contribute to water regulation in cities. Furthermore, parks, wastelands, and a riparian forest (reference area) were adopted as other permeable urban areas for comparison. The results were obtained from one-year monitoring of the soil density, humidity, hydraulic conductivity, infiltration velocity, and soil penetration resistance of urban permeable soils with different uses in Sorocaba, São Paulo, Brazil.

\section{Materials and Methods}

\subsection{Study Area}

Data was collected from the urban area of Sorocaba, São Paulo, Brazil. The city is in the southeast of the state, $92 \mathrm{~km}$ away from the capital São Paulo, on the border of peripheral São Paulo depression [47]. According to the Koeppen classification, the climate is Cwa (tropical altitude), defined by rainy periods in summer and winter droughts, with average minimums of $12{ }^{\circ} \mathrm{C}$ and maximums of $30^{\circ} \mathrm{C}$, and average annual temperature $22.1^{\circ} \mathrm{C}$. The regular annual rainfall is around $1311 \mathrm{~mm}$, and the median altitude is $580 \mathrm{~m}$ [48].

Sorocaba has an area of $449 \mathrm{~km}^{2}$, with a population of approximately 660,000 inhabitants, $99 \%$ of them living in urban areas [49]. The predominant biome in the region is the Atlantic Forest, with plant formations of Seasonal Semideciduous Forest and Dense Ombrophilous Forest. In addition, some regions have an ecotone area between Atlantic Forest and Cerrado, with the presence of phytophysiognomies: Cerrado, Cerrado fields, 
and Floodplain forests [50]. The pedological unit is characterized by Red Latosols and Red-Yellow Argisols [51].

For this study, seven permeable urban areas were selected: one riparian forest, two urban gardens, two parks, and two wastelands. (Figures 1 and 2). One of the gardens (Garden 2) ended its activities in the third month of analysis and was replaced by another garden with similar characteristics. The garden was family-run, developed on a private plot of land that had been ceded for this activity, but was taken over for a building construction.

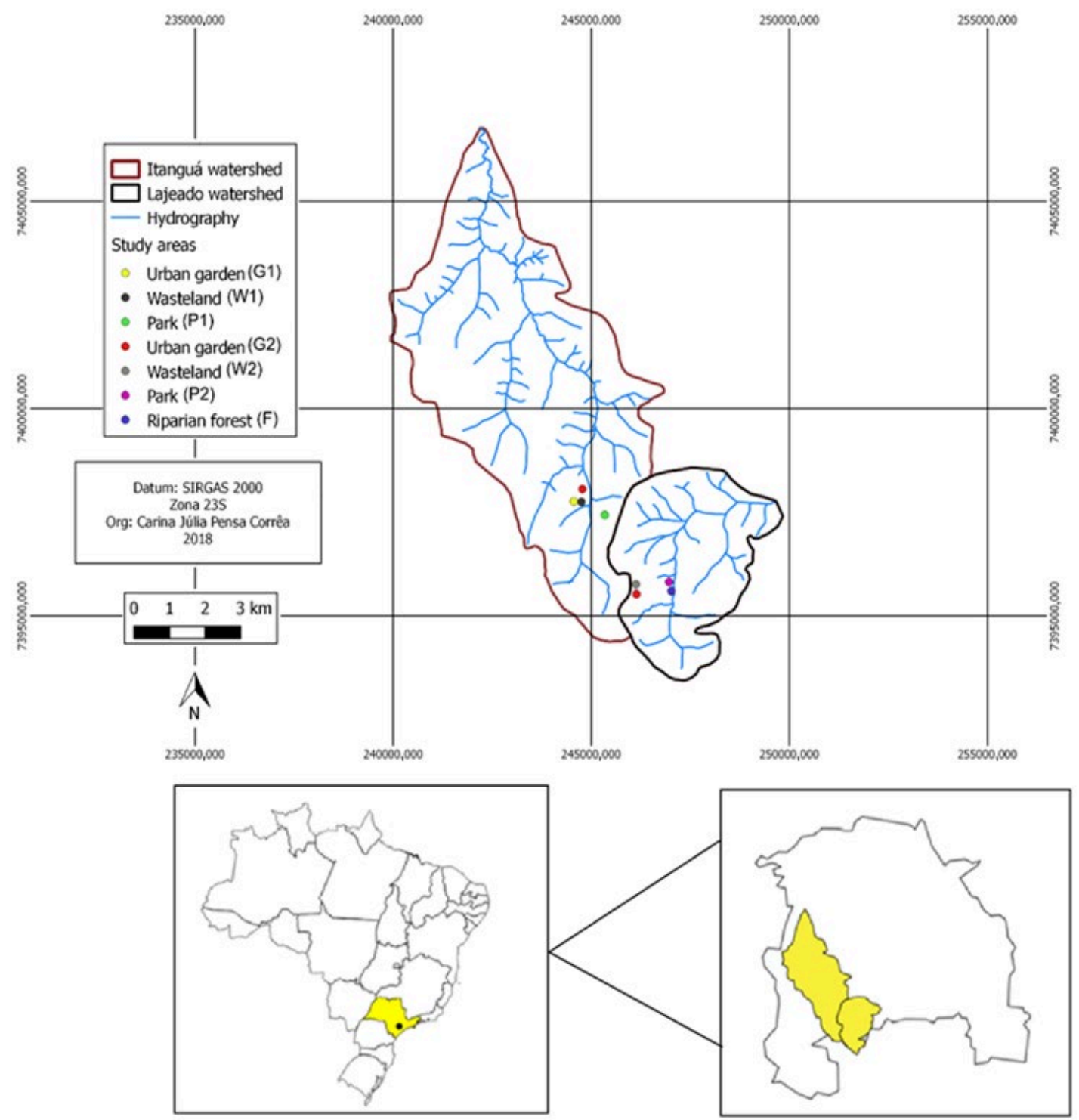

Figure 1. Study areas in the Itanguá and Lageado watersheds, Sorocaba, São Paulo, Brazil.

The watercourses in the Itanguá watershed were channeled with no riparian forest or with restricted access, limiting the fieldwork. Therefore, the chosen forest in the Lageado watershed had a large extension, which allowed measurements to be taken at different points in the region and different distances from the watercourse. To equal the difference in the number of collections, the analysis was performed by grouping the same land uses. Thus, only four treatments were considered at this stage: G (mean of G1 and G2); W (mean of W1 and W2); P (mean P1 and P1); and F.

The riparian forest is not adequate, according to the Brazilian Forest Code [52]. Some problems were identified: a residence near to the water body, chickens foraging, and frequently burning of garbage. The wastelands have some places covered with grasses and some areas with exposed soil. Illegal garbage disposal is frequent, and both wastelands 
are used as parking lots. The parks are mostly covered by grasses. The remaining area includes trees, exposed soil, and infrastructures such as pathways and playgrounds. All these areas have been in the same use and land cover for at least ten years, according to satellite images from Google Earth.
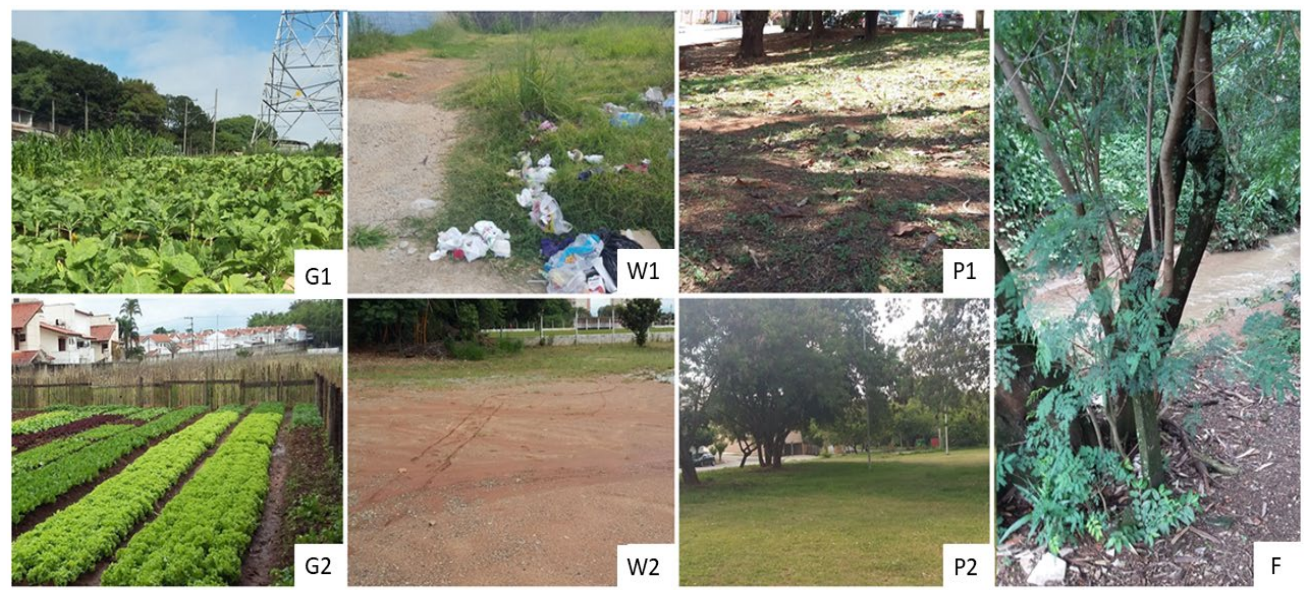

Figure 2. Study areas. (G1,G2) urban gardens; (W1,W2), Wastelands; (P1,P2), parks; and (F), riparian forest. Sorocaba, São Paulo, Brazil, 2019.

The gardens are mostly covered by edible herbaceous species (lettuce, cabbage, arugula, spinach, spices, and medicinal herbs) as well as some fruit trees. The urban garden practices began in 1997 in G1, and since 2016 in G2-previously wasteland. An important characteristic is that both gardens are organic and follow agroecological practices, such as green cover, compost, high diversity, and crop rotation.

\subsection{Precipitation}

During the period in which data collection was conducted, Sorocaba-São Paulo presented less than normal rainfall (Figure 3), especially in February. The months of November and August stand out for presenting larger volumes of rain than expected for the period. Although there were discrepancies, the characteristics of a tropical altitude climate were observed [53].

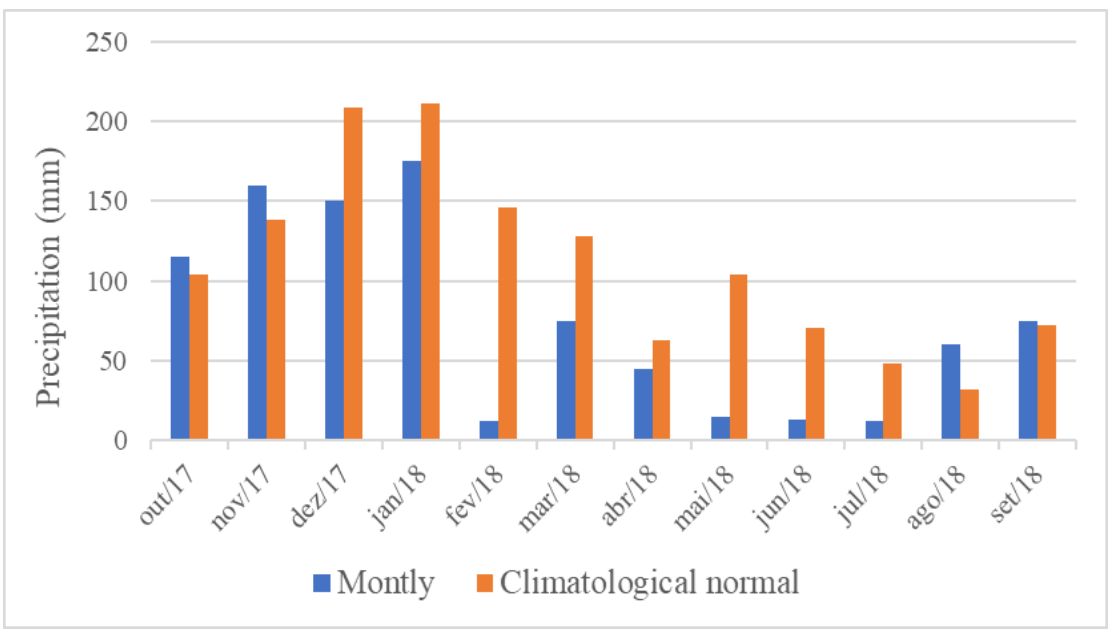

Figure 3. Precipitation (mm) from October 2017 to September 2018 and the climatological normal in Sorocaba, São Paulo, Brazil. Climatological normal corresponded as average values calculated over a relatively long and uniform period, comprising at least three consecutive decades (in this case, between 1961 and 1990). 


\subsection{Soil Indicators}

Monthly sample collections were performed in the selected areas, between October 2017 and September 2018, totaling 12 samples. For all indicators, three repetitions were conducted in each area, and the average was the final value. During this period, ffive soil indicators were analyzed: density $\left(\mathrm{g} \mathrm{cm}^{-3}\right)$, volumetric humidity (\%), hydraulic conductivity $\left(\mathrm{mm} \mathrm{h}^{-1}\right)$, soil water infiltration rate $\left(\mathrm{mm} \mathrm{h}^{-1}\right)$, and Soil Penetration Resistance $(\mathrm{MPa})$. The infiltration rate was determined with the aid of the Minidisk Decagon Infiltrometer, with a suction range adjusted to $-2 \mathrm{~cm} \mathrm{~s}^{-1}$ for all areas and $30 \mathrm{~s}$ measurements until the results stabilized. As the infiltration velocity calculation depends on the soil type, a soil particle size analysis was performed using the pipette method.

Volumetric humidity and density were calculated using soil control rings with a capacity of $100 \mathrm{~cm}^{3}$. After field collection, the soil was weighed (wet weight) and placed to dry in the greenhouse at $105-110^{\circ} \mathrm{C}$ for $24 \mathrm{~h}$, according to Brazilian Agricultural Research Corporation recommendation [54]. After drying and cooling of the samples, they were weighed again (dry weight). For resistance to penetration, the equipment provided the values in $\mathrm{MPa}$ for each centimeter of the soil $(0-60 \mathrm{~cm})$, with maximum strength limit of $7 \mathrm{MPa}$.

\subsection{Data Analysis}

For the calculation of hydraulic conductivity, a spreadsheet provided by the manufacturer of the Infiltrometer-Minidisk was used, with the equations for predicting the hydraulic conductivity of unsaturated soils $[55,56]$. The soil texture influences the calculation; therefore, it was adjusted according to the classification: Garden 1, Wasteland 1, Garden 2 and Park 2-Sandy clay; Park 1 and Riparian Forest-Sandy clay loam; and Wasteland 2-Sandy loam. The volumetric humidity was calculated using the equation:

$$
\mathrm{Ug}=[(\mathrm{a}-\mathrm{b}) / \mathrm{v}] \times 100
$$

where $\mathrm{a}$ is the wet sample mass $(\mathrm{g})$; $\mathrm{b}$ is the dry sample mass $(\mathrm{g})$; and $\mathrm{v}$ is the ring volume $\left(\mathrm{cm}^{3}\right)$. Bulk density was calculated using the equation:

$$
\text { Ds }=a / b
$$

where $a$ is the dry sample mass $(\mathrm{g})$ and $\mathrm{b}$ is the ring volume $\left(\mathrm{cm}^{3}\right)$. Water infiltration rate was calculated using the equation:

$$
\mathrm{Vi}=\mathrm{I} / \mathrm{T}
$$

where I is the cumulative infiltration $(\mathrm{mm})$ and $\mathrm{T}=$ time $(\mathrm{h})$. All the formulas were presented by the Soil Analysis Methods Manual (Brazilian Agricultural Research Corporation, 2011)

Statistical analysis was conducted to compare the results found in the areas, using the Minitab 19 Statistical Software. Initially, a Shapiro-Wilk normality test was performed to compare the means. Statistical analysis was carried out to compare the results found in the areas through PAST 3.23 software. A Shapiro-Wilk normality test, analysis of variance (ANOVA), and Tukey Test were employed. Finally, to compare the adopted parameters, the Pearson Correlation Coefficient was used. The charts were generated by Microsoft Excel Microsoft Office 365 2020, and the map by QGIs 3.4.14.

\section{Results}

\subsection{Bulk Density}

Soil density $(\rho b)$ can be evaluated in different soil strata $[57,58]$. In this case, the first stratum $(0-10 \mathrm{~cm})$ was chosen. $\mathrm{F}\left(1.7 \mathrm{~g} \mathrm{~cm}^{-3}\right)$ presented the lowest mean value, followed by $G$ and $P\left(1.8 \mathrm{~g} \mathrm{~cm}^{-3}\right)$. W had the higher density, with $1.9 \mathrm{~g} \mathrm{~cm}^{-3}$. Considering that all areas have medium texture soil, the results presented higher values than expected in at least one month but there was no significant difference, even with different soil cover. Although unexpected, this result could also be found in other studies [59] (Figure 4). 


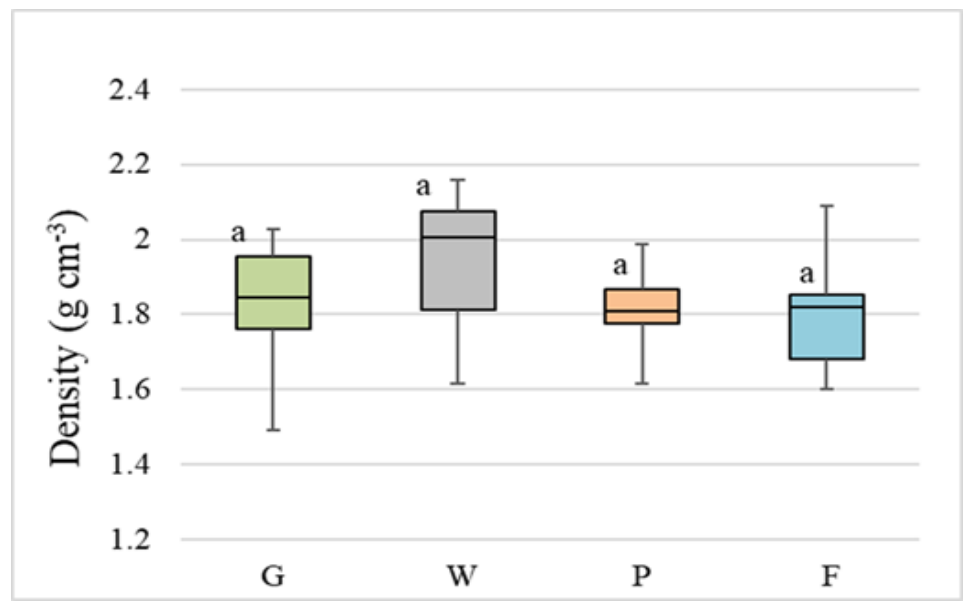

Figure 4. Box plot diagram of bulk density rates $\left(\mathrm{g} \mathrm{cm}^{-3}\right)$. Different letters mean significant differences at $p<0.05$ according to Tukey Test. G, urban gardens; W, wastelands; P, parks; and F, riparian forest.

\subsection{Volumetric Humidity}

When it comes to growing and maintaining vegetation in the urban environment, moisture is one of the determining factors. Both high humidity and water stress conditions can increase plant species mortality [60], and humidity values lower than 10\% may influence the permanent wilting point [61]. The riparian forest had this critical measure in the dry season months: June (8.7\%), July (2.4\%), and August (8.6\%) (Figure 5).

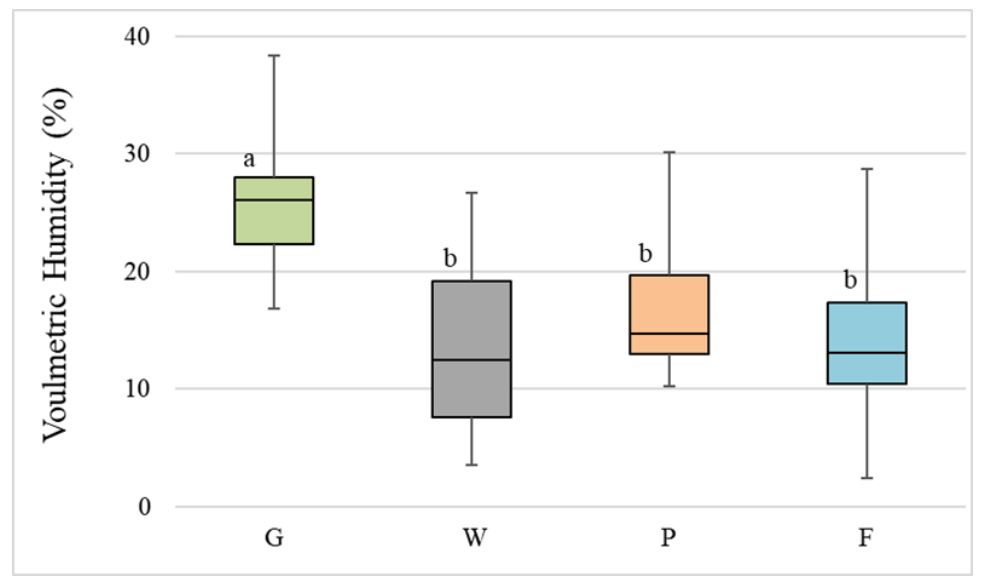

Figure 5. Box plot diagram of volumetric humidity values (\%). Different letters mean significant differences at $p<0.05$ according to Tukey Test. G, urban gardens; W, wastelands; P, warks; and F, riparian forest.

Statistically, G was superior and presented a high humidity rate. Forest $(14.4 \%)$ and parks (17\%) means, on the other hand, did not differ from wastelands $(17 \%)$ on this parameter. In addition to presenting the highest mean $(25.8 \%)$, $\mathrm{G}$ also had the highest moisture recorded for the evaluated period, in November (39.15\%) and January (32.57\%). Although irrigation may favor the water maintenance in agricultural areas, seasonal variation shows that the rainfall influenced this parameter.

\subsection{Hydraulic Conductivity and Infiltration Velocity}

The measurements were performed on unsaturated soil in situ [62]. Although the values found are below expectations in saturated soil experiments, $\mathrm{G}$ also had the highest conductivity $\left(35.8 \mathrm{~mm} \mathrm{~h}^{-1}\right)$ and was significantly higher than all other areas. The lowest average conductivity found was in $\mathrm{W}\left(15.7 \mathrm{~mm} \mathrm{~h}^{-1}\right)$. (Figure 6). 


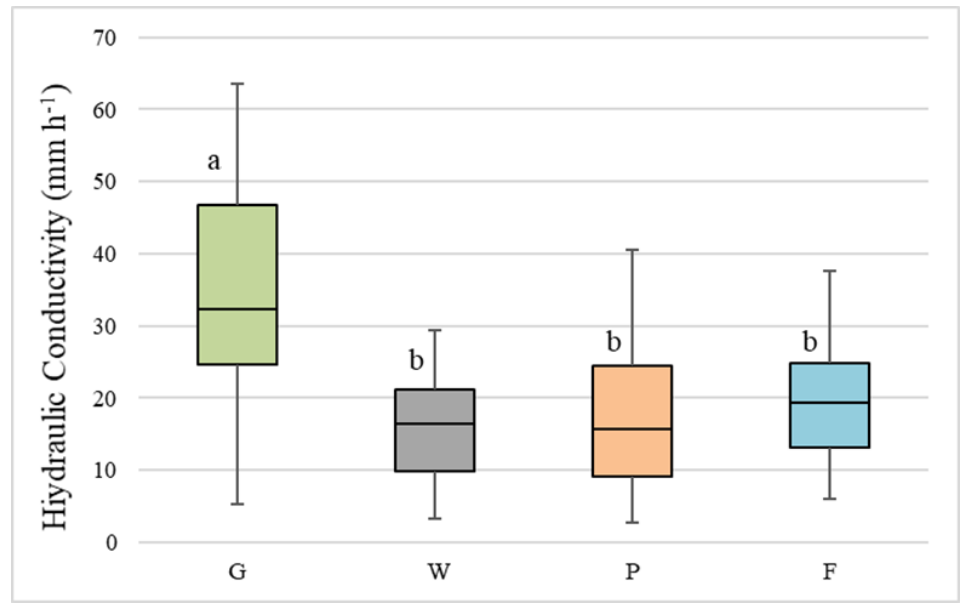

Figure 6. Box plot diagram of hydraulic conductivity values $\left(\mathrm{mm} \mathrm{h}^{-1}\right)$. Different letters mean significant differences at $p<0.05$ according to Tukey Test. G, urban gardens; W, wastelands; P, parks; and $\mathrm{F}$, riparian forest.

Hydraulic conductivity is directly proportional to soil water infiltration velocity in saturated soils. Thus, a moderate positive correlation of these two was found for $\mathrm{W}$, and a strong correlation for G, F, and P. Factors such as soil type and surface influence the water movement in the soil. For this reason, calculations consider the soil texture. Following the previous results, G, again, shows the highest infiltration rates, with an average of 193.4 $\mathrm{mm} \mathrm{h}^{-1}$. The other areas have lower means: $\mathrm{P}=132.8 \mathrm{~mm} \mathrm{~h}^{-1}, \mathrm{~F}=121.9 \mathrm{~mm} \mathrm{~h}^{-1}$, and $\mathrm{W}=118.4 \mathrm{~mm} \mathrm{~h}^{-1}$ (Figure 7).

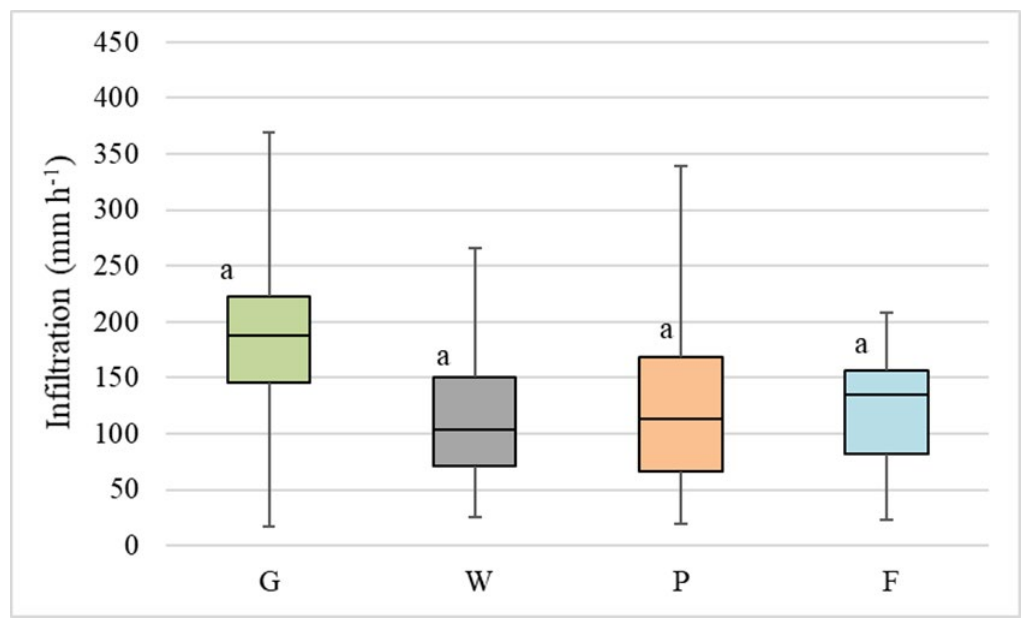

Figure 7. Box plot diagram of infiltration rate values $\left(\mathrm{mm} \mathrm{h}^{-1}\right)$. Different letters mean significant differences at $p<0.05$ according to Tukey Test. G, urban gardens; W, wastelands; $\mathrm{P}$, parks; and F, riparian forest.

\subsection{Soil Penetration Resistance}

In SPR, three factors are fundamental for analysis: average force, peak force, and maximum depth reached. According to the ranges proposed by the manufacturer of the PenetroLOG, the tolerable level of strength is below $2 \mathrm{MPa}$, the intermediate level is between 2 and $3.5 \mathrm{MPa}$, and the critical level is above $3.5 \mathrm{MPa}$. The equipment cannot measure values above $7 \mathrm{MPa}$. For this reason, the absence of measures indicates that the device was unable to penetrate, showing high soil compaction at the site (Figure 8). 


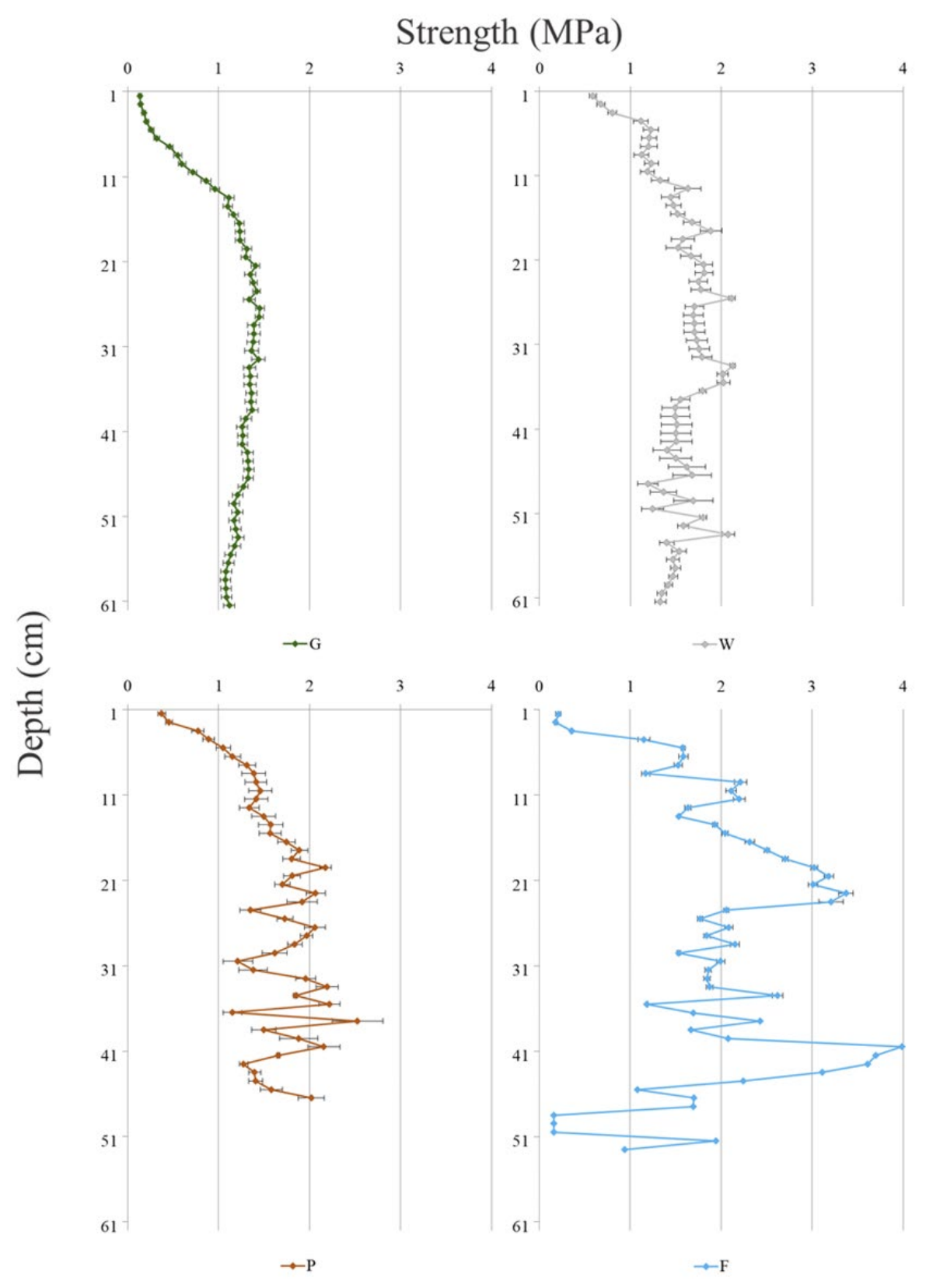

Figure 8. Soil penetration resistance (MPa) until $60 \mathrm{~cm}$ depth. $\mathrm{G}$, urban gardens; $\mathrm{W}$, wastelands; $\mathrm{P}$, parks; and $\mathrm{F}$, riparian forest.

\section{Discussion}

Ideally, non-constructed areas can infiltrate water and contribute to groundwater recharge and reduce runoff [63]. This process should be even more representative in green spaces such as riparian forests and parks [64]. However, this study has shown that urban vegetated areas can be sealed, reducing their potential for providing ecosystem services to cities. Our results presented higher values of density than those observed in other studies [65-69]. Nevertheless, there are few studies of bulk density in urban areas, since forest or rural soils used for agriculture and pasture are more explored [70-74]. In general, medium-textured Brazilian soils may vary from $1.20 \mathrm{~g} \mathrm{~cm}^{-3}$ to $1.80 \mathrm{~g} \mathrm{~cm}^{-3}$ [51], so the means between $1.7 \mathrm{~g} \mathrm{~cm}^{-3}$ and $1.9 \mathrm{~g} \mathrm{~cm}^{-3}$ are within the expected.

Humidity has a positive relationship with the amount of organic matter [35], and the garden presented good values throughout the year. Even for urban and small-scale sites, the values are compatible with rural agriculture areas, indicating that areas are being effectively managed with litter addition $[38,39,75,76]$. Constant irrigation applied by 
farmers can contribute to this moisture and can also improve soil enzyme activity [77]. The favorable scenario is important for maintaining plant productivity, as soil physic-chemical conditioning is crucial to maintain plant water status [37].

Moreover, infiltration rates are dynamic in time and depend on antecedent soil moisture [78]. The gardens presented both highest humidity and water infiltration. In a superficial layer, the increase in the organic matter content also is responsible for reducing SPR [79], and the longevity of the organic compound's benefits can last for five years [80]. In urban gardens, the SPR means in the first layer of the soil can have a mean of $0.28 \mathrm{MPa}$ [34] This value is close to what we found $(0.35 \mathrm{MPa})$. Additionally, if compared to agroforestry systems, the gardens in this study demonstrated good rates of SPR. Systems intercropped with cocoa can reach averages of $3.86 \mathrm{MPa}$, with rubber $1.73 \mathrm{MPa}$, cupuaçu $2.19 \mathrm{MPa}$, and peach $2.84 \mathrm{MPa}$ in the first $10 \mathrm{~cm}$ of the soil [81].

Due to the litter natural deposition, areas with trees were expected to have good moisture values $[82,83]$. However, the critical moisture of the riparian forest in some months indicates an issue related to this soil property. In addition, SPR values high and uneven indicate that the soil is compacted. In Atlantic Forests, an average of $0.89 \mathrm{MPa}$ can be found [84]. In Brazilian Cerrado, the mean of SPR in the first $10 \mathrm{~cm}$ was $0.42 \mathrm{Mpa}$ in a 46-years restoration fragment, $0.22 \mathrm{Mpa}$ in 11-years, and $0.24 \mathrm{Mpa}$ in 8 years [85]. Considering both cases, values were lower than we found in the urban forest (1.2 Mpa).

Urbanization affects the quantity and quality of soil organic matter, and anthropic interventions may be an explanation for this result. Similar results obtained in urban forests indicate that these interventions affect soil physical and chemical parameters [86]. Due to the proximity to residences, the area is used for animal husbandry, garbage disposal, and criminal fire events. Rehabilitation of underground soil and application of proper techniques to minimize and mitigate external negative factors can also be key to the improvement [87-89].

Parks and wastelands are more difficult to evaluate because there are few studies directed to these soils. In a study of areas covered by vetiver grasses (maximum value of 2.0 Mpa), they obtained better results when compared to areas with exposed soil (maximum value of $2.5 \mathrm{Mpa}$ [ [90]. According to the authors, this favorable environment with higher humidity is created by plants in their rhizosphere. A similar conclusion was described in another study, where penetration was lower in soils with vegetation cover than in bare soils [91].

Thus, it was expected that the squares would present lower values of RMPS when compared to vacant lots, especially as they present larger areas covered by grass. However, the peak force of the park (2.5 Mpa) was higher than in the wasteland (2.1 Mpa). This result may indicate that different grass species may vary the contribution to soil physical features. In addition, the preparation of the ground for the establishment of a square must be considered, as well as paths that prevent the population from constantly walking in the grassy areas.

\section{Conclusions}

The positive performance of urban gardens in relation to water management can provide incentives for public policies to encourage initiatives by urban farmers, especially in spaces that do not bring benefits to society and the environment, such as wastelands. Parks also have the potential for diversified use, with the establishment of urban gardens and other green infrastructures in its perimeter. With few permeable spaces in large urban centers, the diversification and multiplication of ecosystem services provided by these spaces could serve to improve environmental quality in cities.

These observed characteristics are especially important in countries such as Brazil, where disorderly urban growth and real estate speculation have had several impacts on green spaces, as demonstrated by the garden that was closed during the study and the water supply issues observed. Hence, these findings are expected to guide environmental 
planning to include the preservation of urban riparian forests, the improvement of parks, the reframing of wastelands, and the adoption of urban gardens.

It is important to highlight that the replication of studies comparing soil physical characteristics may be important in other regions and socio-environmental contexts. Factors such as area history, management, and physical characteristics can influence the results, and future studies in different locations could contribute to further exploring how green areas contribute to urban water management.

Author Contributions: Conceptualization, methodology, C.J.P.C. and K.C.T.; Validation, F.U.M. and E.O.N.; formal analysis, C.J.P.C.; investigation, C.J.P.C. and K.C.T.; data curation, C.J.P.C. and K.C.T.; writing-original draft preparation, C.J.P.C.; writing—review and editing, K.C.T., E.O.N. and F.U.M. All authors have read and agreed to the published version of the manuscript.

Funding: This research was funded by Coordination for the Improvement of Higher Education Personnel-CAPES through the Postgraduate Program in Planning and Using of Renewable Resources, Environmental Science Department, Federal University of São Carlos, São Paulo, Brazil, Finance Code 001 .

Institutional Review Board Statement: Not applicable.

Informed Consent Statement: Not applicable.

Data Availability Statement: Data are contained within the article.

Conflicts of Interest: The authors declare no conflict of interest.

\section{References}

1. Chenoweth, J.; Anderson, A.R.; Kumar, P.; Hunt, W.F.; Chimbwandira, S.J.; Moore, T.L.C. The interrelationship of green infrastructure and natural capital. Land Use Policy 2018, 75, 137-144. [CrossRef]

2. Hopkins, K.G.; Grimm, N.B.; York, A.M. Influence of governance structure on green stormwater infrastructure investment. Environ. Sci. Policy 2018, 84, 124-133. [CrossRef]

3. Halecki, W.; Stachura, T. Evaluation of soil hydrophysical parameters along a semiurban small river: Soil ecosystem services for enhancing water retention in urban and suburban green areas. Catena 2021, 196, 104910. [CrossRef]

4. Bonneau, J.; Fletcher, T.D.; Costelloe, J.F.; Burns, M.J. Stormwater infiltration and the 'urban karst' -A review. J. Hydrol. 2017, 552, 141-150. [CrossRef]

5. Douglas, I. The challenge of urban poverty for the use of green infrastructure on floodplains and wetlands to reduce flood impacts in intertropical Africa. Landsc. Urban Plan. 2018, 180, 262-272. [CrossRef]

6. Li, C.; Yang, Z.; Chiang, P.-C.; Cai, Y.; Wang, X.; Peng, C. Mechanisms and applications of green infrastructure practices for stormwater control: A review. J. Hydrol. 2019, 568, 626-637. [CrossRef]

7. Onuma, A.; Tsuge, T. Comparing green infrastructure as ecosystem-based disaster risk reduction with gray infrastructure in terms of costs and benefits under uncertainty: A theoretical approach. Int. J. Disaster Risk Reduct. 2018, 32, 22-28. [CrossRef]

8. Richards, P.J.; Williams, N.S.G.; Fletcher, T.D.; Farrell, C. Can raingardens produce food and retain stormwater? Effects of substrates and stormwater application method on plant water use, stormwater retention and yield. Ecol. Eng. 2017, 100, 165-174. [CrossRef]

9. Semeraro, T.; Pomes, A.; Del Giudice, C.; Negro, D.; Aretano, R. Planning ground based utility scale solar energy as green infrastructure to enhance ecosystem services. Energy Policy 2018, 117, 218-227. [CrossRef]

10. Shackleton, C.M.; Blair, A.; De Lacy, P.; Kaoma, H.; Mugwagwa, N.; Dalu, M.T.; Walton, W. How important is green infrastructure in small and medium-sized towns? Lessons from South Africa. Landsc. Urban Plan. 2018, 180, 273-281. [CrossRef]

11. Zhang, S.; Muñoz Ramírez, F. Assessing and mapping ecosystem services to support urban green infrastructure: The case of Barcelona, Spain. Cities 2019, 92, 59-70. [CrossRef]

12. Zhang, K.; Chui, T.F.M. Linking hydrological and bioecological benefits of green infrastructures across spatial scales-A literature review. Sci. Total Environ. 2019, 646, 1219-1231. [CrossRef] [PubMed]

13. Zölch, T.; Rahman, M.A.; Pfleiderer, E.; Wagner, G.; Pauleit, S. Designing public squares with green infrastructure to optimize human thermal comfort. Build. Environ. 2019, 149, 640-654. [CrossRef]

14. Harrington, E.; Hsu, D. Roles for government and other sectors in the governance of green infrastructure in the U.S. Environ. Sci. Policy 2018, 88, 104-115. [CrossRef]

15. Li, F.; Liu, Y.; Engel, B.A.; Chen, J.; Sun, H. Green infrastructure practices simulation of the impacts of land use on surface runoff: Case study in Ecorse River watershed, Michigan. J. Environ. Manag. 2019, 233, 603-611. [CrossRef] [PubMed]

16. Herzog, C.P. A multifunctional green infrastructure design to protect and improve native biodiversity in Rio de Janeiro. Landsc. Ecol. Eng. 2016, 12, 141-150. [CrossRef] 
17. Berland, A.; Shiflett, S.A.; Shuster, W.D.; Garmestani, A.S.; Goddard, H.C.; Herrmann, D.L.; Hopton, M.E. The role of trees in urban stormwater management. Landsc. Urban Plan. 2017, 162, 167-177. [CrossRef] [PubMed]

18. Trees and Permeable Paving: Future Symbionts. Available online: https://treenet.org/resources/trees-and-permeable-pavingfuture-symbionts / (accessed on 5 July 2021).

19. Trees. Available online: http:/ / www.permavoid.co.uk/solutions/trees/ (accessed on 5 July 2021).

20. Barwise, Y.; Kumar, P. Designing vegetation barriers for urban air pollution abatement: A practical review for appropriate plant species selection. NPJ Clim. Atmos. 2020, 3, 12. [CrossRef]

21. Soak Up the Rain: Trees Help Reduce Runoff. Available online: https:/ / www.epa.gov/soakuptherain/soak-rain-trees-helpreduce-runoff (accessed on 7 July 2021).

22. Kirnbauer, M.C.; Baetz, B.W.; Kenney, W.A. Estimating the stormwater attenuation benefits derived from planting four monoculture species of deciduous trees on vacant and underutilized urban land parcels. Urban For. Urban Green. 2013, 12, $401-407$. [CrossRef]

23. Samara, T.; Tsitsoni, T. The effects of vegetation on reducing traffic noise from a city ring road. Noise Control Eng. J. 2011, 59, 68-74. [CrossRef]

24. The Role of Urban Trees and Greenspaces in Reducing Urban Air Temperatures. Available online: https://www.forestresearch. gov.uk/documents/7125/FCRN037.pdf (accessed on 4 July 2021).

25. Turner-Skoff, J.B.; Cavender, N. The benefits of trees for livable and sustainable communities. Plants People Planet 2019, 1, $323-335$. [CrossRef]

26. Ogueke, N.V.; Nwakanma, A.F.; Ngharamike, T. Energy-saving potentials of some local trees. Energy Effic. 2017, 10, 171-181. [CrossRef]

27. Isaifan, R.J.; Baldauf, R.W. Estimating economic and environmental benefits of urban trees in desert regions. Front. Ecol. Evol. 2020, 8, 16. [CrossRef] [PubMed]

28. Wang, X.; Gard, W.; Borska, H. Vertical greenery systems: From plants to trees with self-growing interconnections. Eur. J. Wood Wood Prod. 2020, 78, 1031-1043. [CrossRef]

29. Mello, K.; Valente, R.A.; Randhir, T.O.; Santos, A.C.A.; Vettorazzia, C.A. Effects of land use and land cover on water quality of low-order streams in Southeastern Brazil: Watershed versus riparian zone. Catena 2018, 167, 130-138. [CrossRef]

30. Aerts, R.; Dewaelheyns, V.; Achten, W.M.J. Potential ecosystem services of urban agriculture: A review. Potential Ecosyst. Serv. Urban Agric. 2016, 4, 2286v1. [CrossRef]

31. Davis, A.Y.; Lonsdorf, E.V.; Shierk, C.R.; Matteson, K.C.; Taylor, J.R.; Lovell, S.T.; Minor, E.S. Enhancing pollination supply in an urban ecosystem through landscape modifications. Landsc. Urban Plan. 2017, 162, 157-166. [CrossRef]

32. Rogers, C.M.; Hiner, C.C. Siting urban agriculture as a green infrastructure strategy for land use planning in Austin, TX. Chall. Sustain. 2016, 4, 39-53. [CrossRef]

33. Pulighe, G.; Fava, F.; Lupia, F. Insights and opportunities from mapping ecosystem services of urban green spaces and potentials in planning. Ecosyst. Serv. 2016, 22, 1-10. [CrossRef]

34. Correa, C.J.P.; Tonello, K.C.; Nnadi, E. Urban gardens and soil compaction: A land use alternative for runoff decrease. Environ. Process. 2021, 8, 1213-1230. [CrossRef]

35. Hillel, D. Introduction to Soil Physics; Elsevier Academic Press: Amsterdam, The Netherlands, 1983.

36. Hillel, D. Introduction to Environmental Soil Physics; Elsevier Academic Press: Amsterdam, The Netherlands, 2003.

37. Silva, B.M.; Oliveira, G.C.; Serafim, M.E.; Silva, É.A.; Guimarães, P.T.G.; Melo, L.B.B.; Norton, L.D.; Curi, N. Soil moisture associated with least limiting water range, leaf water potential, initial growth and yield of coffee as affected by soil management system. Soil Tillage Res. 2019, 189, 36-43. [CrossRef]

38. Purdy, A.J.; Fisher, J.B.; Goulden, M.L.; Colliander, A.; Halverson, G.; Tu, K.; Famiglietti, J.S. SMAP soil moisture improves global evapotranspiration. Remote Sens. Environ. 2018, 219, 1-14. [CrossRef]

39. Singh, H.V.; Thompson, A.M. Effect of antecedent soil moisture content on soil critical shear stress in agricultural watersheds. Geoderma 2016, 262, 165-173. [CrossRef]

40. Cui, G.; Zhu, J. Prediction of unsaturated flow and water backfill during infiltration in layered soils. J. Hydrol. 2018, 557, 509-521. [CrossRef]

41. Villela, S.M.; Mattos, A. Applied Hydrology; McGraw-Hill: São Paulo, Brazil, 1975.

42. Santos, T.E.M.; De Souza, E.R.; Montenegro, A.A.A. Modeling of soil water infiltration with rainfall simulator in different agricultural systems. Rev. Bras. Eng. Agríc. Ambient. 2016, 518, 513-518. [CrossRef]

43. Loáiciga, H.A.; Johnson, J.M. Infiltration on sloping terrain and its role on runoff generation and slope stability. J. Hydrol. 2018, 561, 584-597. [CrossRef]

44. Eekhout, J.P.C.; Vente, J. Global impact of climate change on soil erosion and potential for adaptation through soil conservation. Earth-Sci. Rev. 2022, 226, 103921. [CrossRef]

45. Marcinkowskia, P.; Szporak-Wasilewskab, S.; Kardela, I. Assessment of soil erosion under long-term projections of climate change in Poland. J. Hydrol. 2022, 607, 127468. [CrossRef]

46. Bungau, S.G.; Behl, T.; Lotfi, A.; Bourgeade, P.; Aloui-Sossé, B.; Purza, A.L.; Abid, A.; Samuel, A.D. Expatiating the impact of anthropogenic aspects and climatic factors on long term soil monitoring and management. Environ. Sci. Pollut. Res. 2021, 202, 30528-30550. [CrossRef] [PubMed] 
47. Map of Hydrographic Units for Water Resources Management. Available online: http://www.igc.sp.gov.br/produtos/ugrhi.html (accessed on 23 February 2021).

48. Municipal Climates. Available online: http://www.cpa.unicamp.br/outrasinformacoes/clima_muni_228.html (accessed on 19 March 2020).

49. Estimated Population. Available online: https://www.ibge.gov.br/estatisticas/sociais/populacao.html (accessed on 5 March 2020).

50. Ministry of Science and Technology. Atlas of the Forest Remnants of the Atlantic Forest: 2008-2010 Period; SOS Atlantic Forest and National Institute for Space Research: São Paulo, Brazil, 2011.

51. Brazilian Agricultural Research Corporation. Pedological Map of the State of São Paulo. Scale 1:500,000; EMBRAPA Soil: Rio de Janeiro, Brazil, 1999.

52. Law n. 12651, Provides for the Protection of Native Vegetation. Available online: http://www.planalto.gov.br/ccivil_03/_Ato201 1-2014/2012/Lei/L12651.htm (accessed on 20 April 2020).

53. Climate. Available online: http:/ / www.inmet.gov.br/portal/index.php?r=clima/graficosClimaticos (accessed on 14 March 2020).

54. Brazilian Agricultural Research Corporation. Manual of Soil Analysis Methods, 2nd ed.; EMBRAPA Soil: Rio de Janeiro, Brazil, 2011.

55. Van Genuchten, M.T. A closed-form equation for predicting the hydraulic conductivity of unsaturated soils. Soil Sci. Soc. Am. J. 1980, 44, 892-898. [CrossRef]

56. Zhang, R. Determination of soil sorptivity and hydraulic conductivity from the disk infiltrometer. Soil Sci. Soc. Am. J. 1997, 61, 1024-1030. [CrossRef]

57. Al-Shammary, A.A.G.; Kouzani, A.Z.; Saeed, T.R.; Lahmod, N.R.; Mouazen, A.M. Evaluation of a novel electromechanical system for measuring soil bulk density. Biosyst. Eng. 2019, 179, 140-154. [CrossRef]

58. Li, S.; Li, Q.; Wang, C.; Li, B.; Gao, X.; Li, Y.; Wu, D. Spatial variability of soil bulk density and its controlling factors in an agricultural intensive area of Chengdu Plain, Southwest China. J. Integr. Agric. 2019, 18, 290-300. [CrossRef]

59. Sone, J.S.; Oliveira, P.T.S.; Euclides, V.P.B.; Montagner, D.B.; Araujo, A.R.; Zamboni, P.A.P.; Vieira, N.O.M.; Carvalho, G.A.; Sobrinho, T.A. Effects of nitrogen fertilisation and stocking rates on soil erosion and water infiltration in a Brazilian Cerrado farm. Agric. Ecosyst. Environ. 2020, 304, 107159. [CrossRef]

60. Allen, C.D.; Macalady, A.K.; Chenchouni, H.; Bachelet, D.; Mcdowell, N.; Vennetier, M.; Kitzberger, T.; Rigling, A.; Breshears, D.D.; Hogg, E.H.T.; et al. A global overview of drought and heat-induced tree mortality reveals emerging climate change risks for forests. For. Ecol. Manag. 2010, 259, 660-684. [CrossRef]

61. Scheberl, A.L.; Scharenbroch, B.C.; Les, P.; Prater, J.R.; Fite, K.L. Evaluation of soil pH and soil moisture with different field sensors: Case study urban soil. Urban For. Urban Green. 2019, 38, 267-279. [CrossRef]

62. Tian, Z.; Kool, D.; Ren, T.; Horton, R.; Heitman, J.L. Approaches for estimating unsaturated soil hydraulic conductivities at various bulk densities with the extended Mualem-van Genuchten model. J. Hydrol. 2019, 572, 719-731. [CrossRef]

63. Wakode, H.B.; Baier, K.; Jha, R.; Azzam, R. Impact of urbanization on groundwater recharge and urban water balance for the city of Hyderabad, India. Int. Soil Water Conserv. Res. 2018, 6, 51-62. [CrossRef]

64. Zhipeng, L.; Donghao, M.; Wei, H.; Xuelin, L. Land use dependent variation of soil water infiltration characteristics and their scale-specific controls. Soil Tillage Res. 2018, 178, 139-149. [CrossRef]

65. Martín, M.Á.; Reyes, M.; Taguas, F.J. Estimating soil bulk density with information metrics of soil texture. Geoderma 2017, 287, 66-70. [CrossRef]

66. Matsinhe, D.Z.; Pereira, S.B.; de Oliveira, R.A.; de Assis, I.R.; Oliveira, R.M. Use of PVC pipes to determine bulk density for irrigation management. Rev. Cienc. Agron. 2019, 50, 27-37. [CrossRef]

67. Premrov, A.; Cummins, T.; Byrne, K.A. Bulk-density modelling using optimal power-transformation of measured physical and chemical soil parameters. Geoderma 2018, 314, 205-220. [CrossRef]

68. Reichert, J.M.; Mentges, M.I.; Rodrigues, M.F.; Cavalli, J.P.; Awe, G.O.; Mentges, L.R. Compressibility and elasticity of subtropical no-till soils varying in granulometry organic matter, bulk density and moisture. Catena 2018, 165, 345-357. [CrossRef]

69. Xiangsheng, Y.; Guosheng, L.; Yanyu, Y. Pedotransfer functions for estimating soil bulk density: A case study in the three-river headwater region of Qinghai province, China. Pedosphere 2016, 26, 362-373. [CrossRef]

70. De Bonetti, J.A.; Paulino, H.B.; de Souza, E.D.; Carneiro, M.A.C.; Caetano, J.O. Soil physical and biological properties in an integrated crop-livestock system in the Brazilian Cerrado. Pesqui. Agropecu. Bras. 2018, 53, 1239-1247. [CrossRef]

71. Fin, S.S.; Marchesan, E.; Gubiani, P.I.; Farenzena, J.A.P.; Murari, M.S.; Coelho, L.L.; Filho, A.C.; Aramburu, B.B. Duration of the effects of scarification and raised bed associated with vegetation cover on soybean yield on an Alfisol. Pesqui. Agropecu. Bras. 2018, 53, 1230-1238. [CrossRef]

72. Levinski-Huf, F.; Klein, V.A. Organic matter and physical properties of a red latosol under an integrated crop-livestock-forestry system. Pesqui. Agropecu. Trop. 2018, 48, 316-322. [CrossRef]

73. De Medeiros, A.S.; da Silva, T.S.; da Silva, A.V.L.; Barros, D.R.S.; Maia, S.M.F. Organic carbon, nitrogen and the stability of soil aggregates in areas converted from sugar cane to eucalyptus in the State of Alagoas. Rev. Árvore 2018, 42, e420404. [CrossRef]

74. Silva, D.M.N.; Venturim, C.H.P.; Valory Capucho, M.E.O.; de Oliveira, F.L.; de Sá Mendonça, E. Impact of soil cover systems on soil quality and organic production of yacon. Sci. Hortic. 2018, 235, 407-412. [CrossRef] 
75. Martins, A.P.; de Costa, S.E.V.G.A.; Anghinoni, I.; Kunrath, T.R.; Cecagno, D.; Reichert, J.M.; Balerini, F.; Dillenburg, L.R.; de Carvalho, P.C.F. Soil moisture and soybean physiology affected by drought in an integrated crop-livestock system. Pesqui. Agropecu. Bras. 2016, 51, 978-989. [CrossRef]

76. Wieder, W.; Shoop, S.; Barna, L.; Franz, T.; Finkenbiner, C. Comparison of soil strength measurements of agricultural soils in Nebraska. J. Terramech. 2018, 77, 31-48. [CrossRef]

77. Samuel, A.D.; Brejea, R.; Domuta, G.; Bungau, S.G.; Cenușa, N.; Tit, M.D. Enzymatic indicators of soil quality. J. Environ. Prot. Ecol. 2017, 18, 871-878.

78. Phillips, T.H.; Baker, M.E.; Lautar, K.; Yesilonis, I.; Pavao-Zuckerman, M.A. The capacity of urban forest patches to infiltrate stormwater is influenced by soil physical properties and soil moisture. J. Environ. Manag. 2019, 246, 11-18. [CrossRef] [PubMed]

79. Lan, T.; Guo, S.W.; Han, J.W.; Yang, Y.L.; Zhang, K.; Zhang, Q.; Yang, W.; Li, P.F. Evaluation of physical properties of typical urban green space soils in Binhai Area, Tianjin, China. Urban For. Urban Green. 2019, 44, 126430. [CrossRef]

80. Kranz, C.N.; McLaughlin, R.A.; Johnson, A.; Miller, G.; Heitman, J.L. The effects of compost incorporation on soil physical properties in urban soils-A concise review. J. Environ. Manag. 2020, 261, 110209. [CrossRef] [PubMed]

81. Cherubin, M.R.; Chavarro-Bermeo, J.P.; Silva-Olaya, A.M. Agroforestry systems improve soil physical quality in northwestern Colombian Amazon. Agrofor. Syst. 2019, 93, 1741-1753. [CrossRef]

82. Peng, Y.; Holmstrup, M.; Schmidt, I.K.; Schrijver, A.D.; Schelfhout, S.; Heděnec, P.; Zheng, H.; Bachega, L.R.; Yue, K.; Vesterdal, F. Litter quality, mycorrhizal association, and soil properties regulate effects of tree species on the soil fauna community. Geoderma 2022, 407, 115570. [CrossRef]

83. Tresch, S.; Frey, D.; Bayon, R.L.; Rasche, F.; Fliessbach, A.; Moretti, M. Litter decomposition driven by soil fauna, plant diversity and soil management in urban gardens. Sci. Total Environ. 2018, 658, 1614-1629. [CrossRef]

84. Martinkoski, L.; Vogel, G.F.; Jadoski, S.O.; Watzlawick, L.F. Soil physical quality under silvopastoral management and secondary forest. For. Environ. 2017, 24, e20160282. [CrossRef]

85. Pereira, L.C.; Balbinot, L.; Matus, G.N.; Dias, H.C.T.; Tonello, K.C. Aspects of forest restoration and hydrology: Linking passive restoration and soil-water recovery in Brazilian Cerrado. J. For. Res. 2021, 32, 2301-2311. [CrossRef]

86. Chai, L.; Huang, M.; Fan, H.; Wang, J.; Jiang, D.; Zhang, M.; Huang, Y. Urbanization altered regional soil organic matter quantity and quality: Insight from excitation emission matrix (EEM) and parallel factor analysis (PARAFAC). Chemosphere 2019, 220, 249-258. [CrossRef] [PubMed]

87. Layman, R.M.; Day, S.D.; Mitchell, D.K.; Chen, Y.; Harris, J.R.; Daniels, W.L. Below ground matters: Urban soil rehabilitation increases tree canopy and speeds establishment. Urban For. Urban Green 2016, 16, 25-35. [CrossRef]

88. Almeida, W.S.; Panachuki, E.; Oliveira, P.T.S.; Silva Menezes, R.; Sobrinho, T.A.; Carvalho, D.F. Effect of soil tillage and vegetal cover on soil water infiltration. Soil Tillage Res. 2018, 175, 130-138. [CrossRef]

89. Wang, G.; Huang, W.; Mayes, M.A.; Liu, X.; Zhang, D.; Zhang, Q.; Han, T.; Zhou, G. Soil moisture drives microbial controls on carbon decomposition in two subtropical forests. Soil Biol. Biochem. 2019, 130, 185-194. [CrossRef]

90. Chado, L.; Holanda, F.S.R.; Pedrotti, A.; Ferreira, O.J.M.; Filho, R.N.A.; Moura, M.M. Effect of vetiver roots on soil resistance to penetration in a typic fluvic neossol in the são francisco riverbank. Caatinga 2018, 31, 935-943.

91. Mongil-Manso, J.; Navarro-Hevid, J.; Díaz-Gutiérrez, V.; Cruz-Alonso, V.; Ramos-Díez, I. Badlands forest restoration in central Spain after 50 years under a Mediterranean-continental climate. Ecol. Eng. 2016, 97, 313-326. [CrossRef] 